\title{
PROBABLE BARN OWL RECORDS FOR MANITOBA
}

ROBERT W. NERO, Box 14, 1495 St. James Street, Winnipeg, Manitoba, R3H OW9

Although the Prairie Provinces are outside the usual range of the Barn Owl, ${ }^{1,4,9}$ various species of owls found inside buildings in this region are sometimes mistakenly called "Barn Owls" by inexperienced observers. Reports of "Barn Owls" here, therefore, tend to be regarded with a little scepticism. Great Horned Owls, Boreal Owls and Northern Saw-whet Owls are suspect species since these birds now and then, especially in winter, are found in buildings. Great Horned Owls occasionally nest in old barns and all three species have been found sheltering in out-buildings. Boreal Owls in Alaska hàve been observed using deserted igloos for shelter; starving birds in New England have entered buildings even in villages and cities. ${ }^{2}$ Even the Barred Owl has been observed inside a building - in this case, nesting! - though this must be considered an exceptional case (pers. comm., C. S. Houston, 1992).

A bird identified as a Barn Owl and described to me on 15 March 1988 by Sandra Rex of Holland, Manitoba, however, seems likely to have been a genuine Barn Owl. According to Mrs. Rex, this bird was seen by four members of her family as it perched on a rafter in a barn on their farm 8 $\mathrm{km}$ northwest of Holland. This was in the fall, probably September, in about 1985 . The owl, which was present for about 10 days, had a "creamy-coloured face" and "lacked horns." At first, because the bird was so pale, it was thought to be a Snowy Owl, but it had "a dark line around a heart-shaped face" similar to that of the Barn Owl illustration in their copy of Godfrey's Birds of Canada. ${ }^{4}$ Mrs. Rex added that the bird in their barn was "paler than the one in the book." Although they did not see the owl hunting, they believe it was "after swallows and mice" which were in and about the barn.

More recently, what was believed to be a Barn Owl was observed by Arnold Collins at Pilot Mound, about $40 \mathrm{~km}$ south of Holland. Collins, who has been interested in birds for 70 years, found this bird at dusk perched on a hydro wire by an old yard site with a shed and trees near his home about $2 \mathrm{~km}$ west of town. This was in the last week of November 1991 (pers. comm., 24 January 1992). Although he had no binoculars when viewing the bird, Collins recalled that he was struck by the "creamy-coloured clown-like face ... a peculiar face with an oval-shaped lighter ring under each eye." $\mathrm{He}$ thought it an odd-looking owl, unlike any he'd ever seen, and thought it strange to be perched on a hydro wire. He identified it as a Barn Owl shortly thereafter when he looked in one of his three field guides. When I pressed him for further details, he emphasized the "buff-coloured face" and a "short tail." When I suggested that he check the shed, he mentioned that on more than one occasion a Great Horned Owl had wintered there, sitting up on an eave.

Usually, specimen records provide 
strong evidence of the occurrence of a species. Although the following must be regarded as a possible record, it should be noted that the circumstances make it rather tenuous. On 20 November 1990, I was asked by the Canadian Wildlife Service in Winnipeg to identify bird remains seized from a traveller on his way home from Canada to Mexico. Included were two partial wings from a Barn Owl. These had supposedly come from a road-killed bird found somewhere in Manitoba on 8 February 1990.

According to Johnsgard, Barn Owls rarely nest north of North Dakota and southern Minnesota, the main breeding range being farther south. ${ }^{9}$ Reported as a "causal permanent resident in the southern half" of Minnesota, they are now of rare occurrence there. ${ }^{5}$

Birders looking for owls hereabouts should consider inspecting old barns and sheds for possible occupants. At least in winter, Boreal Owls may be found in barns more often than Barn Owls. Note that records of Barn Owls in the Prairie Provinces have been mainly of birds observed outside of barns $3,6,7,8,10,11,12$

\section{AMERICAN ORNITHOLOGISTS'} UNION. 1983. Check-list of North
American birds, 6th ed. Washington D.C. Am. Ornithol. Union. 877 pp.

2. BENT, A.C. 1938. Life histories of North American birds of prey. U.S. Natl. Mus. Bull. 167, part 2. Dover reprint, $1961.482 \mathrm{pp}$.

3. FOX, G.A. 1963. A possible recent record of the Barn Owl in Saskatchewan. Blue Jay 21:104.

4. GODFREY, W.E. 1986. The birds of Canada (revised ed.). Natl. Mus. of Canada. 595 pp.

5. GREEN, J.C. and R.B. JANSSEN. 1975. Minnesota birds, where, when, and how many. Univ. Minn. Press, Minneapolis, MN. 217 pp.

6. HARRIS, W.C. 1988. Prairie Provinces Region. Am. Birds 42:93.

7. MOSSOP, H. 1960. "Chickadee Notes," No. 299, Winnipeg Free Press, 7 Oct. 1960.

8. SHORTT, A.H. 1960. "Wild Wings," Winnipeg Tribune, 21 Nov. 1960.

9. JOHNSGARD, P.A. 1988. North American owls: biology and natural history. Smithsonian Inst. Press., Washington, D.C. 295 pp.

10. SMITH, H.C. 1967. Report on Barn Owl at Regina. Blue Jay 25:22.

11. SMITH, W. 1967. The Barn Owl in Alberta. Blue Jay 25:187.

12. TAYLOR, P. 1983. Wings along the Winnipeg, the birds of the Pinawa-Lac du Bonnet region, Manitoba. Man. Naturalists Soc. EcoSeries No. 2, Winnipeg. $216 \mathrm{pp}$.

Spring comes to each tiny stitch in the snow quilt as a single moment. Molecules in the ice lattice soak up energy from the sun until they break the close tie they may have held all winter with their neighbours. In that supreme moment, essential to all life, ice becomes liquid. It is the fluid instant. Braun \& Cavagnara. 1971. Living Water. American West, Palo Alto, CA. 


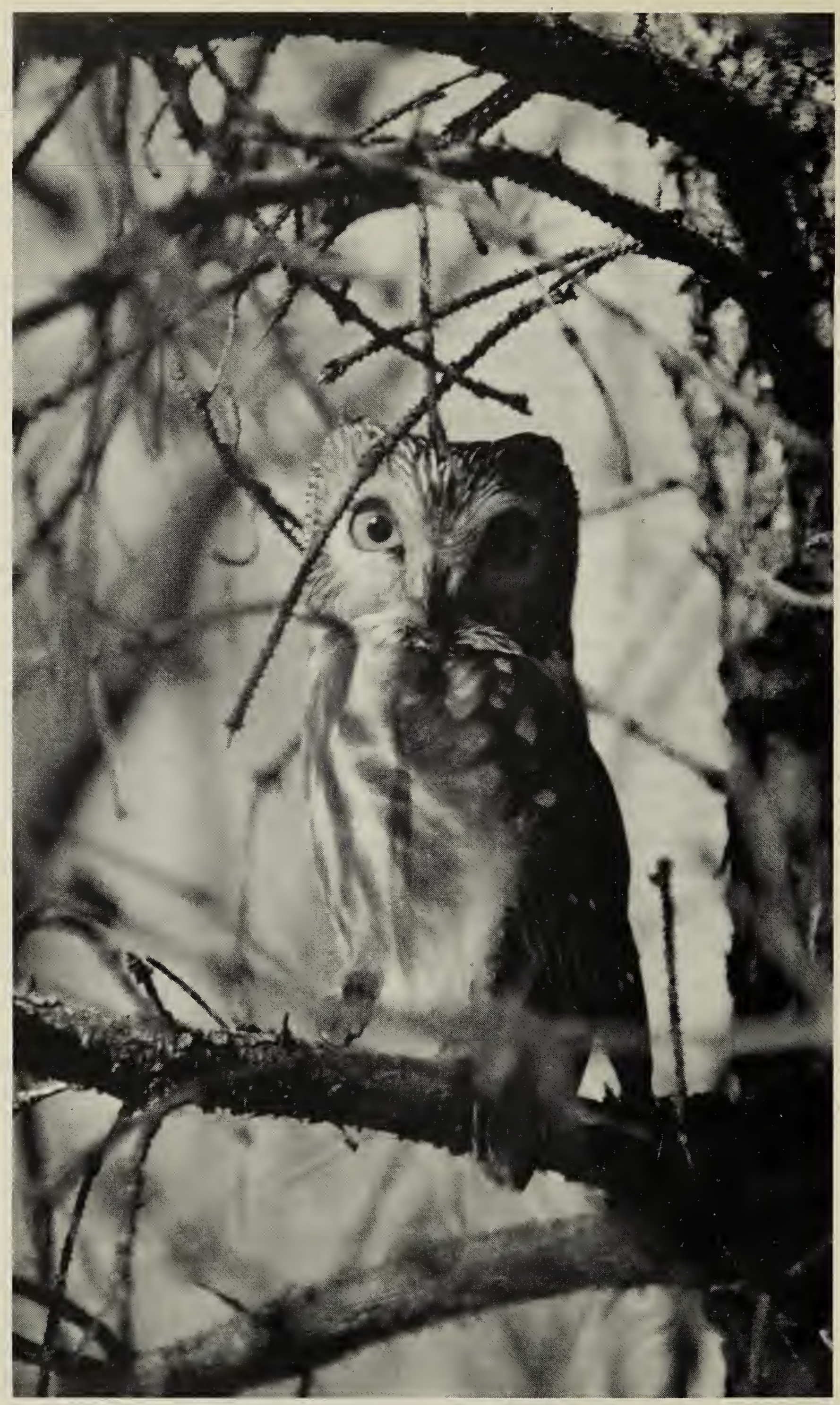

Saw-whet Owl, Coulter Field, Weyburn, at Souris Valley Regional Care Centre grounds.

Val Doyle 